\title{
Work Readiness: a Review of the Influence of Industrial Practice and Vehicle Tune-Up Competency
}

\author{
Suyitno S. ${ }^{1}$, Dwi Jatmoko², Muhammad Nurtanto ${ }^{3}$, R. Rabiman ${ }^{4}$, W. Warju ${ }^{5}$, Sulaeman Deni \\ Ramdani ${ }^{6}$ \\ \{yitno@umpwr.ac.id $\left.{ }^{1}\right\}$ \\ Department of Automotive Engineering Education, Universitas Muhammadiyah Purworejo, Jawa \\ Tengah, Indonesia ${ }^{1,2}$ \\ Department of Mechanical Engineering Education, Universitas Sultan Ageng Tirtayasa, Serang, Banten, \\ Indonesia ${ }^{3,6}$ \\ Department of Mechanical Engineering Education, Universitas Sarjanawiyata Tamansiswa, Yogyakarta, \\ Indonesia $^{4}$ \\ Department of Mechanical Engineering, Universitas Negeri Surabaya, Jawa Timur, Indonesia ${ }^{5}$
}

\begin{abstract}
This study aims to examine the effect of industrial practice work programs and vehicle tune-up competencies on job readiness. A quantitative research using an ex-post facto approach was selected to test hypotheses based on existing facts. 169 respondents were selected as part of the cluster randomization technique. The data were collected through tests and observations and analyzed using the SPSS software. The results showed that (1) there was a positive effect on practical work programs on job readiness with a contribution of $14.7 \%$; (2) positive influence of tune-up engine competency on job readiness with a contribution of $72.1 \%$; and (3) both have the effect of $23.3 \%$ simultaneously. The important factors in preparing for employment are the supply of vocational training students prior to the implementation of industrial practice programs and increased opportunities to put development drivers into practice.
\end{abstract}

Keywords: Industrial work practices, tune-up competence, job readiness

\section{Introduction}

Vocational education has an important role in developing human resources in each country [1], [2], it has even become a global trend. Several countries have succeeded in providing vocational education. One indicator of the success of vocational education is the decline in unemployment [3], and the absorption of graduates in work, continuing and entrepreneurship according to their field of expertise [4]. However, according to BPS data, vocational education contributed to a high unemployment rate of $8.49 \%$ in February 2020. The highest contributor was adolescents aged $15-24$ years at $16.28 \%$. This figure shows that vocational student readiness is being questioned again. How vocational students form the competencies needed in the industrial world.

Work readiness is a priority factor for vocational students [5]-[7]. Do so far vocational students in implementing school learning have an impact on job acceptance in the industry. Work readiness in the vocational field, especially in the automotive sector, is influenced by the implementation of industrial practice programs and competence in the field of expertise, namely vehicle tuning. One of the link and match policies in Indonesia is through industrial practice 
programs [8], [9]. The industrial practice program is an apprenticeship program equivalent to a dual system education in which vocational students develop their experience in the industry directly. Through this program, vocational students have many benefits, including (1) students can learn directly to face consumers; (2) carrying out an industrial work culture; and (3) accepted to work after graduation, if they have industry standard qualifications [10]. Thus, the industrial practice program becomes a catalyst for vocational students in applying and directly learning the characteristics of the world of work. The problems that arise are the students' unpreparedness in mastering the basic competencies and opportunities given in the limited industrial world, as well as incomplete trust from the industry [11]-[13].

Work readiness is also influenced by student competence during academic studies at vocational schools. In this study, the correlation is determined from one of the competencies commonly needed in the automotive industry, namely Tune up engine [14], [15]. Vocational students who have certain abilities can take competency tests to obtain national standard legality and become portfolio documents that are considered specifically in the industrial world (trust value) [16][17]. However, the problem that often occurs is that vocational students are not directly involved in implementing practices or limited practical opportunities, resulting in the lack of insight they have [18] [19].

The results of observations that have been carried out at a vocational school, PurworejoIndonesia, found the tune-up engine competency based on the value of learning completeness, more than $60 \%$ of vocational students were declared incompetent. Other problems also occur, due to the choice of a simple industrial workplace. The results of interviews that have been conducted by several vocational students chose industrial workplaces in simple places with consideration of the proximity to their homes. The researcher's analysis is based on the secondary data, that the readiness of students needs to be tested for its effect. The hypothesis in this study is (H1) how the influence of industrial work practice programs on automotive student work readiness in vocational schools. (H2) how the influence of vehicle tune-up competence on automotive student work readiness in vocational schools. (H3) how the influence of industrial work practice programs and vehicle tune-up competencies together on automotive student work readiness in vocational schools. This influence test recommends a high-impact relationship value and is used as a reference for comparison for other vocational schools.

\section{Method}

This research is a quantitative study with an ex post facto approach, adapted from Neil [20]. This study believed that experimental research was conducted to test the hypothesis in treatment [21], [22]. In theory, work readiness correlates with programs, industry work practices, and vehicle tuning competencies. The number of respondents in the study was 169 people selected in the cluster random sampling consisting of 10 classes. The data were collected using a test sheet and an observation sheet in the form of a questionnaire. The data analysis was performed using the analysis, prerequisite test, namely the normality test, current test, multicollinearity test, and hypothesis testing using SPSS software. 


\section{Result and discussion}

\subsection{Normality test}

The normality test uses the Kolmogorov Smirnov $\mathrm{Z}$ test to calculate the residual value with the acquisition of 0.924 with a probability value of 0.360 . The probability value $(\mathrm{p}=0.360$ > $0.05)$, then the data is normal and tests for linearity.

\subsection{Linearity test}

Linearity testing aims to determine the pattern of relationships between variables. If the probability value is greater than 0.05 then the variable is formed linearly. The value obtained by the variable industrial work practice program on job readiness is obtained by df $14, \mathrm{~F}$ of 1.075 and $\mathrm{p}=0.384$, greater than 0.05 . and the value obtained by the vehicle tune-up competency variable on work readiness is obtained $\mathrm{df} 7, \mathrm{~F}$ is 9,940 and $\mathrm{p}=0.875$ is greater than 0.05 , so both variables are linear.

\subsection{Multicollinearity test}

The multicollinearity test is a multiple regression assumption test by comparing the VIF value. The industrial work practice program variable obtained a tolerance value of 0.934 with a VIF value of $1.070<10$, so there was no multicollinearity. Whereas in the vehicle tune-up competency variable, it was obtained a tolerance value of 0.934 with a VIF value of $1.070<10$, so there was no multicollinearity.

\subsection{Hypothesis test}

Figure 1 shows the correlation between IWP program and tune up engine competence on work readiness.

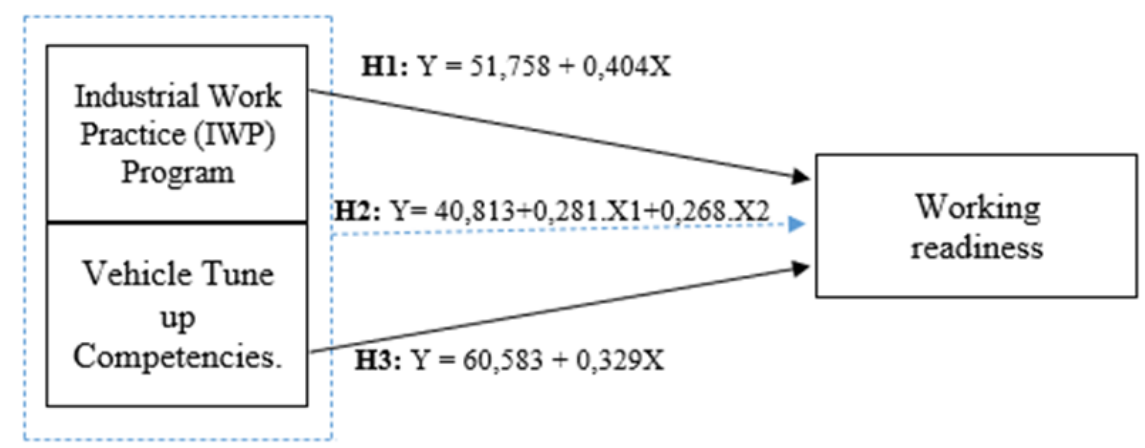

Fig. 1. Correlation between IWP program and tune up engine competence on work readiness

\subsection{Discussion}

Based on the results of research on the effect of industrial work practices and vehicle tuneup competence on work readiness using multiple regression analysis, the equation $\mathrm{Y}=40.813$ 
$+0.281 \mathrm{X} 1+0.286 \mathrm{X} 2$ is obtained with a constant value for the regression model equation is 40.813 , this shows that without work practices industry and state tune-up competence, then student work-readiness can still improve. The test results of the effect of industrial work practices on job readiness obtained $t_{\text {coun }} t 4.184>t_{\text {table }}(1.645)$ with a p-value of $0.00<0.005$ so that the hypothesis is accepted, meaning that there is an effect of industrial work practices on job readiness. Thus, the higher the value of industrial work practices, the student's work readiness will increase [23][24].

The test results of the effect of tune-up vehicle competence on student work readiness were obtained 0.420 and tcount 5.977> t table (1.645) with a p-value of $0.00<0.005$ so that the hypothesis is accepted, meaning that there is an effect of vehicle tune-up competence on student work readiness. Thus, the higher the tune-up competency value of the vehicle, the student's work readiness will increase [25]. There is a positive and significant influence jointly between industrial work practices and vehicle tune-up competence on student work readiness obtained by Fcount 23.309> Ftable (2.99) with a p-value of $0.00<0.005$, so the hypothesis is accepted.

\section{Conclusion}

Based on the results of the discussion above, it can be taken, namely (1) there is a positive influence of industrial work practices on vocational student work readiness with the contribution of the influence of industrial work practices on job readiness is 0.147 or $14.7 \%$, (2) there is an influence of vehicle tune-up competence on vocational student work readiness with the contribution of the influence of vehicle tune-up competence to work readiness is 0.721 or $72.17 \%$, (3) there is a positive influence on industrial work practices and vehicle tune-up competence on vocational student work readiness with a contribution of 0.219 or $21.9 \%$. The size of the relative contribution was $100 \%$, while the effective contribution was $23.304 \%$. Recommendations from the study results, namely (1) vocational schools are deemed necessary to provide competencies relevant to the industrial world, and (2) emphasize the opportunity to practice tune-up engines.

\section{References}

[1] K. Mellahi, 'Human resource development through vocational education in Gulf Cooperation Countries: the case of Saudi Arabia', J. Vocat. Educ. Train., vol. 52, no. 2, pp. 329-344, Jun. 2000, doi: 10.1080/13636820000200119.

[2] O. Okorafor and P. Okorafor, 'Technical, Vocational Education and Training (TVET) for Human Resource Development (HRD) in the Emerging Knowledge Economy', The Intuition, vol. 5, pp. 150-161, Jan. 2013.

[3] M. Alagaraja and N. Arthur-Mensah, 'Exploring technical vocational education and training systems in emerging markets: A case study on Ghana', Eur. J. Train. Dev., vol. 37, no. 9, pp. 835-850, Jan. 2013, doi: 10.1108/EJTD-04-2013-0037.

[4] Z. Arifin, M. Nurtanto, W. Warju, R. Rabiman, and N. Kholifah, 'The TAWOCK conceptual model at content knowledge for professional teaching in vocational education', Int. J. Eval. Res. Educ. IJERE, vol. 9, no. 3, Art. no. 3, Sep. 2020, doi: 10.11591/ijere.v9i3.20561.

[5] F. Tentama, N. Merdiaty, and S. Subardjo, 'Self-efficacy and work readiness among vocational high school students', J. Educ. Learn. EduLearn, vol. 13, no. 2, Art. no. 2, May 2019, doi: 10.11591/edulearn.v13i2.12677. 
[6] E. Putriatama, S. Patmanthara, and M. Sugandi, Work readiness by vocational school graduates viewed from industrial work practice's experience and vocational skills, vol. 1778. 2016.

[7] Gunadi, H. Sofyan, M. Nurtanto, Z. Arifin, and P. Sudira, 'Vocational Teachers Readiness in Face of the Industrial Revolution 4.0: Vocational Teachers Perceptions in Yogyakarta-Indonesia', J. Phys. Conf. Ser., vol. 1700, p. 012082, Dec. 2020, doi: 10.1088/1742-6596/1700/1/012082.

[8] J. Tijaja and M. Faisal, 'Industrial Policy in Indonesia: A Global Value Chain Perspective', p. 51.

[9] A. Rahayu, L. A. Wibowo, and S. Sulastri, 'Analysis of Link and Match Policies in Improving Work Readiness of Vocational Student in West Java', presented at the 3rd Global Conference On Business, Management, and Entrepreneurship (GCBME 2018), Jawa Barat, Indonesia, 2020, doi: 10.2991/aebmr.k.200131.039.

[10] S. Soeryanto, W. Warju, M. Nurtanto, S. R. Ariyanto, and N. Kholifah, 'The use of Google Classroom in improving Learning Achievement on Apprenticeship Program in Vocational Schools', Interencia J., vol. 46, no. 2, pp. 221-231, 2021.

[11] D. Ratnawati, S. Purnomo, N. A. Handoyono, Subagyo, and S. Suyitno, 'Automatization of fog lamp based on LED sensor and photo dioda', J. Phys. Conf. Ser., vol. 1700, p. 012055, Dec. 2020, doi: 10.1088/1742-6596/1700/1/012055.

[12] N. Arifin Handoyono, Suparmin, Samidjo, A. Bintoro Johan, and S. Suyitno, 'Project-based learning model with real object in vocational school learning', J. Phys. Conf. Ser., vol. 1700, p. 012045, Dec. 2020, doi: 10.1088/1742-6596/1700/1/012045.

[13] M. Setiyo et al., "Industry 4.0: Challenges of Mechanical Engineering for Society and Industry," Mechanical Engineering for Society and Industry, vol. 1, no. 1, pp. 3-6, 2021

[14] M. Nurtanto, H. Sofyan, P. Pardjono, and S. Suyitno, 'Development model for competency improvement and national vocational qualification support frames in Automotive technology', Int. J. Eval. Res. Educ. IJERE, vol. 9, no. 1, Art. no. 1, Mar. 2020, doi: 10.11591/ijere.v9i1.20447.

[15] M. Nurtanto, S. Nurhaji, D. Widjanarko, M. Wijaya, and H. Sofyan, 'Comparison of Scientific Literacy in Engine Tune-up Competencies through Guided Problem-Based Learning and NonIntegrated Problem-Based Learning in Vocational Education', J. Phys. Conf. Ser., vol. 1114, p. 012038, Nov. 2018, doi: 10.1088/1742-6596/1114/1/012038.

[16] M. Nurtanto, Z. Arifin, H. Sofyan, W. Warju, and S. Nurhaji, 'Development of Model for Professional Competency Assessment (PCA) in Vocational Education: Study of the Engine TuneUp Injection System Assessment Scheme', J. Tech. Educ. Train., vol. 12, no. 2, Art. no. 2, Feb. 2020, $\begin{array}{lllll}\text { Accessed: } & \text { Jun. } & 30, & \text { Anailable: }\end{array}$ https://publisher.uthm.edu.my/ojs/index.php/JTET/article/view/5152.

[17] S. Suyitno, J. Dwi, S. Arif, and P. Aci, 'Trainer Stand Instructional Media of Wiring System for Kijang Car to Improve Student Achievement in Vocational Higher Education', Jour Adv Res. Dyn. Control Syst., vol. 11, no. 11, pp. 991-997, 2019, doi: 10.5373/JARDCS/V11SP11/20193126.

[18] S. Suyitno, A. Primartadi, D. Jatmoko, M. Nurtanto, and D. Ratnawati, 'The influence of audio visual media on student interest: automotive clutch power train system', J. Phys. Conf. Ser., vol. 1700, p. 012049, Dec. 2020, doi: 10.1088/1742-6596/1700/1/012049.

[19] N. Kholifah, P. Sudira, R. Rachmadtullah, M. Nurtanto, and S. Suyitno, 'The Effectiveness of Using Blended Learning Models Against Vocational Education Student Learning Motivation', p. 6, 2020.

[20] N. Salkind, 'Ex Post Facto Study', in Encyclopedia of Research Design, 2455 Teller Road, Thousand Oaks California 91320 United States: SAGE Publications, Inc., 2010.

[21] C. A. Watson, 'An Ex Post Facto Study on the Relationship Between Self-Reported Peer-to-Peer Mentoring Experiences and Instructor Confidence, Institutional Loyalty, and Student Satisfaction among Part-Time Instructors', p. 281, 2012.

[22] B. Lee, 'Statistical Conclusion Validity in Ex Post Facto Designs: Practicality in Evaluation', Educ. Eval. Policy Anal., vol. 7, no. 1, pp. 35-45, 1985, doi: 10.2307/1164001.

[23] D. Putri and S. Sutarto, 'The effect of industrial work practice, guidance intensity of industrial side, and vocational competence on working readiness of grade XII students of banking program, Vocational High School Perbankan, Pekanbaru', J. Pendidik. Vokasi, vol. 8, p. 132, Jul. 2018, doi: 10.21831/jpv.v8i2.18908. 
[24] M. Feriady and H. Yanto, 'Developing Students Work Readiness Model on Accounting Program of Vocational High School (VHS) Base on I-E-O Astin Model', KnE Soc. Sci., vol. 3, no. 10, p. 77, Oct. 2018, doi: 10.18502/kss.v3i10.3120.

[25] D. Jackson, 'Student Perceptions of the Development of Work Readiness in Australian Undergraduate Programs', J. Coll. Stud. Dev., vol. 60, pp. 219-239, Jan. 2019, doi: 10.1353/csd.2019.0020. 